\title{
WORKING PLANS FOR FARM WOODLOTS
}

\author{
By G. A. Murlloy \\ Dominion Forest Service, Ottawa
}

$\mathrm{T}$

$\mathrm{HE}$ Dominion Forest Service, in co-operation with the Federal Depart. ment of Agriculture, has prepared a series of working plans for woodlots on experimental farms and illustration stations in the Maritime Provinces. The preparation of these working plans has brought to light certain differences in definition which have a direct bearing on the method of procedure in calculation of the allowable annual cut.

The term "Farm Woodlot" is here defined as a small area reserved from cultivation, usually, but not necessarily, occupying the rougher and less fertile part of the farm. It generally occupies from 20 to 40 acres of the average farm. From it the farmer cuts his annual supply of fuelwood and other prod. ucts useful on the farm.

On the other hand, a "Farm Woodland" is an extensive area of wood. land owned by the farmer, which may or may not be adjacent to the farm proper. From it the farmer cuts products such as pulpwood, sawlogs and cordwood for sale, and while his own requirements for fuelwood may be met from the same area, this feature is only incidental to the main business of cutting and selling forest products.

The main difference in these two divisions is that, in the one case, the woodlot is not so much a source of profit as an essential part of the farm, while in the other case, the woodland is an entirely separate business run for profit to augment the income of the farm proper. In the one case an annual income in the form of fuelwood is essential, while in the other case this yearly feature of management is not essential; big returns from the sale of forest products in one year may be followed by a long interval when nothing is harvested.

In formulating working plans, then, these inherent differences in the "objects of management" must be considered, and they will materially affect the methods of regulation and silvicultural treatment. In all working plans the chief feature is the determination of the possible annual cut which may be harvested, and which will at the same time allow the growing stock or capital to be retained at its optimum level, or to be gradually increased if it is understocked. Nearly all farm woodlots are understocked because they have been cut into yearly for many generations. Whether a woodlot is well stocked or not depends on how conservative the management has been.

The determination of the amount of the annual cut depends, of course, upon the annual growth. Because the farm woodlot will be cut over an. nually and because all trees which are defective or likely to die are re. moved, there should be no mortality and therefore, no difference between gross and net increment With continued intensive management, not only will no trees die but none will even approach death, being removed before they have begun to slow up in their rate of growth. 
Furthermore, the selection form of cutting aims at an all-aged forest in which there are trees of all ages from seedlings up to the age at which the most useful wood is produced. In the all-aged forest the current and mean annual increment are the same amount and, therefore, no allowance has to be made for the difference in these two rates of growth. This is a very different concept, and the procedure in determining the permissible annual cut is much simpler than that for an extensive woodland where not only the net, as opposed to the gross current annual increment, but the average net growth over the whole of the rotation, as opposed to the current net growth, have to be determined as the basis of cutting. During the interval in which the farm woodlot is to be brought to its peak of production the calculation of the annual permissible cut can be regulated by keeping it lower than the gross current annual increment. Thus each year part of the current growth is added to the growing stock. How much this is will depend upon the needs of the farm for fuelwood and the level of the present growing stock. The more that is added to this growing stock the sooner it will reach its optimum level and the higher will be the permissible annual cut.

It is often not practical to cut over the entire woodlot for the annual wood supply. In fact, it is not advisable to do so, with the exception that insect-infested or dying trees should be removed wherever they occur. It is simpler and better to divide the woodlot into a number of compartments of more or less equal area. Each year one of these compartments is cut over, taking therefrom the allowable annual cut for the whole woodlot. It is then allowed to remain undisturbed until all the other compartments are cut over. Thus what is called a "cutting cycle" is set up, which corresponds in number of years to the number of compartments.

This compartment principle has several good features. The interval between cuts on any one compartment allows the forest to recover from the shock of disturbance and the remaining trees to increase their rate of growth. Reproduction and young growth also has a chance to become firmly established. Moreover, concentration of cutting on one compartment means a more economical operation.

It will be noted that rotation age and mean annual increment-the factors usually used in calculation of the budget-have not been determined for these farm woodlots. The smallness of the area involved and the condition of stocking prevent the calculation of such factors. They can be determined only after the woodlot has been under full management for many years. But the lack of such data does not prevent regulation of the cut from being initiated. The methods outlined here provide a practical means of regulating the cut on woodlots which are far from normal both in stocking and growth. 